\title{
Źródła antropologii Juliana Haynesa Stewarda
}

\section{Wprowadzenie}

Julian Haynes Steward jest jednym z najbardziej znanych antropologów amerykańskich. W latach pięćdziesiątych XX wieku otrzymał nominację do bardzo prestiżowej National Academy of Sciences. W roku 1955 ukazała się, wielokrotnie wznawiana i najbardziej znana jego książka - Theory of Culture Change, w której opisał swoje najważniejsze antropologiczne koncepcje: ekologię kulturową, jądro kulturowe oraz multilinearną ewolucję kulturową. Najczęściej nazwisko Stewarda jest łączone z kierunkiem antropologicznym określanym jako ekologia kulturowa. Zazwyczaj to właśnie jemu przypisuje się autorstwo tej koncepcji.

Ekologia kulturowa bada wzajemne zależności czynników środowiska, technologii oraz zachowania człowieka. Koncepcja ta używa metod nauk społecznych w celu poznania procesów przystosowania i zmian danych społeczności ze względu na wpływ określonego środowiska naturalnego. ${ }^{1} \mathrm{~W}$ swych badaniach Steward oparł się na założeniu, ze poszczególne kultury wyewoluowały na obszarze lokalnych środowisk, a dokładna analiza relacji pomiędzy konkretnymi instytucjami kulturowymi i cechami środowiska, z którego wyrosły, pozwoli zrozumieć przyczyny powstania kultur, sposób ich funkcjonowania oraz rozwoju lub upadku. ${ }^{2}$

Artykuł ten ma wskazać źródła antropologii Juliana Stewarda. Wydaje się, że najlepszą metodą do zbadania tego zagadnienia będzie zastosowanie metody używanej przez samego Stewarda, który w swych analizach koncentrował się na roli środowiska w kształtowaniu określonej kultury. Dla zbadania ewolucji myśli Stewarda wskaże się na trzy zasadnicze środowiska oraz ich wpływ na kształt jego koncepcji antropologicznych.

1 Por. Robert McC. Net Ting, Cultural Ecology, [w:] David Levinson (red.), Melvin Ember (red.), Encyclopedia of Cultural Anthropology, New York: Henry Holt and Company 1996, Vol. 1, s. 267.

2 Por. K. Milton, Environmentalism and Cultural Thoery. Exploring the role of anthropology in environmental discourse, London-New York: Routledge 1999, s. 43. 
Niezbędnym elementem zbadania źródeł antropologii Stewarda jest bliższe poznanie niektórych faktów z jego życia ponieważ wpłynęły one na sposób jego myślenia. Nakierowały też uwagę Stewarda na określone zagadnienia, które później stały się istotnymi elementami ekologii kulturowej. Innym źródłem inspiracji i ewolucji poglądów tego antropologa była debata w środowisku naukowym na temat jego koncepcji.

Chociaż stanowisko Stewarda było oryginalne, nie sposób jednak zgodzić się z Autorem, że nikt i nic w żadnym stopniu nie przyczyniło się do powstania i kształtu jego ujęcia antropologii. Wydaje się, że źródła inspiracji Stewarda można połączyć z wpływem trzech środowisk oddziałujących na tego uczonego:

- środowisko naturalne i społeczne;

- środowisko rodzinne i wychowawcze;

- środowisko intelektualne;

\section{2. Środowisko naturalne i społeczne}

Początki fascynacji antropologią można zaobserwować u Stewarda już w latach dwudziestych i to zarówno w jego pracach teoretycznych, jak i terenowych. Istotny wpływ na jego podejście do antropologii miał fakt, iż we wczesnym okresie studiów w Deep Springs College przez trzy lata Steward na co dzień stykał się z pracą fizyczną w bardzo surowych warunkach amerykańskiego zachodu. Było to doświadczenie, którego nie mieli jego późniejsi koledzy-antropolodzy. Pierwszy etap studiów Stewarda to praktyczna nauka geologii, zoologii i antropologii, które poznał dzięki temu, że college znajdował się w opuszczonej wyżynnej dolinie Deep Springs. Istotne jest to, że nauka przebiegała niejako dwutorowo: teoretycznie i praktycznie. Miało to kolosalne znaczenie dla wizji świata młodego Juliana Stewarda i sposobu postrzegania tego, co ważne.

Fotografie, które zrobił Steward w czasie pobytu w Deep Springs, wiele mówią o tym, jak widział on świat i co wydawało mu się istotne. Jego fotografie przedstawiają osoby i miejsca, pracujących na ranczu studentów, Indian, znakowanie i karmienie bydła oraz krajobrazy wokół uczelni. Uwiecznił na fotografiach dzikie stoki Deep Springs Valley otoczonej ciągnącymi się po horyzont górami i błękitnym bezchmurnym niebem. To właśnie tam zobaczył wybudowany na pięć lat przed jego przybyciem akwedukt dostarczający wodę do Los Angeles. Na jego oczach pozbawiona wody żyzna i tętniąca życiem dolina stopniowo pustynniała, a bujna roślinność została zastąpiona przez roślinność pustynną. Dostrzegał też stopniowe wysychanie jeziora Owens. Kiedy w roku 1935 odwiedzil swoją dawną uczelnię z jeszcze większą wyrazistością dostrzegł zmiany, jakie zaszły w środowisku naturalnym od czasu, gdy opuścił mury swojej alma mater. Brak wody spowodował kompletne wyschnięcie jeziora, w którym podczas studiów Steward często pływał. Jego osobiste doświadczenia uświadomiły mu ogromną rolę wody 
dla każdej ludzkiej społeczności. Znalazło to swoje odbicie w dalszych jego pracach. $^{3}$

Dużo później doświadczenia Stewarda zdobyte w Deep Springs Valley i Owens Valley znacząco wpłynęły na kształt jego najważniejszej antropologicznej koncepcji - ekologii kulturowej. Ziemia, woda, żywność, technologia i praca mężczyzn uformowały obszar jego intelektualnych zainteresowań, które otrzymały swój odpowiednik w badaniach i publikacjach. Żywe wspomnienia konkretnych miejsc i chwil dostarczyły szablonu dla jego późniejszych badań jako antropologa. W swych pracach Steward wskazywał na korelacje pomiędzy gospodarką zasobami wodnymi, ekonomią i zaludnieniem w pierwotnych cywilizacjach. Virginia Kerns twierdzi nawet, że pobyt Stewarda w Deep Springs można traktować jako „laboratorium ekologii kulturowej”, w którym rozwijały się i dojrzewały późniejsze koncepcje tego antropologa ${ }^{4}$

$\mathrm{Na}$ kształt ekologii kulturowej miały też wpływ osobiste doświadczenia życiowe Stewarda, który przez całe lata poszukiwał pracy i doświadczał problemów ekonomicznych. ${ }^{5}$ Osobistym doświadczeniem związanym z ekologią kulturową było przenoszenie się z miejsca na miejsce $\mathrm{w}$ celu zdobycia środków do utrzymania. W jego wypadku było to szukanie pracy na kolejnych uniwersytetach i w instytucjach rządowych, które umożliwiały mu prowadzenie badań terenowych. ${ }^{6}$ Badania te były niezbędne dla empirycznego potwierdzenia słuszności tez stawianych w ekologii kulturowej. W koncepcji tej, podobnie jak w osobistym życiu Stewarda i jego podejściu do studentów, chodziło o pracę mężczyzn. Kobiety i dzieci były poza zasięgiem jego zainteresowań. Obowiązkiem mężczyzny było zabezpieczanie rodziny i dostarczenie środków do utrzymania, podobnie jak miało to miejsce w pierwotnych patrylinearnych społecznościach myśliwych.?

3 Jedną z najbardziej znanych prac Stewarda związanych z jego badaniami nad znaczeniem wody dla życia danej społeczności jest artykuł Irrigation Without Agriculture, który ukazał się w latach trzydziestych w „Papers of the Michigan Academy of Science, Arts and Letters” oraz jego wystąpienie Irrigation civilizations: a comparative study wygłoszony podczas sympozjum w Waszyngtonie w $1960 \mathrm{r}$. W całej twórczości Stewarda dostrzegamy wielką wagę, jaką przywiązywał do zasobów wody niezbędnej do życia każdej społeczności. Julian Steward dobrze wiedział, jak istotna jest odległość wodopoju od miejsca, gdzie pasie się bydło lub gdzie znajduje się domostwo. Pojenie zwierząt i przywożenie wody pitnej było jednym z jego codziennych zajęć przez ponad trzy lata.

4 Por. V. Kerns, Scenes from the High Desert: Julian Steward's Life and Theory, Urbana-Chicago: University of Illinois Press 2003, s. 7-9.

Por. Tamże, s. 318, 321.

6 Por. Tamże, s. 115.

7 Miało to konkretne przełożenie na pracę Stewarda, który niechętnie patrzył na studentki a szczególnie doktorantki, uważając, że ich miejscem jest dom a podstawowym zajęciem wychowywanie dzieci. Por. V. KerNs, Scenes from the High Desert..., dz. cyt., s. 266-267. 
Pomimo braku stałego zatrudnienia w okresie wielkiego kryzysu ekonomicznego, Steward intensywnie pracował nad koncepcją, którą ostatecznie nazwał ekologią kulturową. Zwracał w niej szczególną uwagę na środowisko naturalne i jego rolę w tworzeniu się lokalnej kultury. Wbrew opiniom niektórych, ${ }^{8}$ większość uczonych uważa, że to Steward był pierwszym antropologiem, który konsekwentnie i systematycznie skupił się na miejscu stykania się kultury i środowiska naturalnego. Zwracał szczególną uwagę na takie zagadnienia, jak krajobraz jako taki, zwierzęta, rośliny i woda. Steward bardzo podkreślał relację pomiędzy technologią (szczególnie narzędziami używanymi przez człowieka w celu zdobycia środków do życia) a pewnymi cechami środowiska: klimatem, zasobami wody, ukształtowaniem terenu, glebą, roślinnością i zwierzętami. Wszystkie te czynniki były dla Stewarda decydujące. W praktyce najwięcej uwagi poświęcał zasobom środowiska naturalnego, szczególnie wodzie i żywności. Lata, które spędził na wyżynnej pustyni, nauczyły go, jak bardzo niedostatek wody wpływa na zdobywanie żywności i strukturę życia społecznego. Obok technologii, Steward podkreślał drugą kluczową cechę kultury - organizację pracy. Uważał, że sposób, w jaki ludzie używają narzędzi i organizują swoją pracę w celu zdobycia środków do życia, wpływa na inne aspekty kultury, począwszy od sposobu osiedlania się, poprzez struktury własności ziemi po struktury pokrewieństwa.

Podróżując w lipcu 1934 r. do miasta Moab w południowo-wschodniej części Utah, Jane i Julian Stewardowie podziwiali wielkie kontrasty tamtejszego krajobrazu, obfitującego $z$ jednej strony w zielone pola okolicznych farm, $\mathrm{z}$ drugiej zaś w nagie czerwone zbocza dolin. Steward uświadomił sobie wówczas wyraźnie, że technologia i zasoby naturalne, szczególnie zaś woda oraz ludzka praca stworzyły te bezpośrednio ze sobą sąsiadujące kontrasty. Osiedla mormonów dzięki systemom irygacyjnym i nakładowi pracy były w stanie zmienić krajobraz w tak dużym stopniu. Wszystkie te czynniki stały się później istotnymi elementami ekologii kulturowej.'

Z kolei w czerwcu 1936 r., badając zwyczaje Szoszonów, Steward zauważył, jak wprowadzenie nowego narzędzia wpłynęło na sposób życia i organizację społeczności indiańskich żyjących na terenie Great Basin. Początkowo Szoszoni traktowali konie jedynie jako źródło pożywienia. Dopiero później zaczęli ich używać jako zwierząt pociągowych oraz środka transportu. Zmiana ta pociągnęła za sobą ogromne przemiany kulturowe na bardzo wielu polach: w sposobie polowania, strukturze społecznej i politycznej. Dzięki tym badaniom Steward dostrzegł, jak zmiana technologii (oswojenie konia) wpłynęło na ekonomię i odmieniło sposób życia tego plemienia. ${ }^{10}$ Niewątpliwie obserwacja ta miała znaczenie dla uwzględ-

8 Por. B. Olszewska-Dyoniziak, Człowiek - kultura - osobowość. Wstęp do klasycznej antropologii kulturowej, Wroclaw: atla 2 2003, s. 56.

9 Por. V. Kerns, Scenes from the High Desert..., dz. cyt., s. 158.

10 Por. Tamże, s. 201. 
nienia tego elementu w ramach ekologii kulturowej. Można więc przypuszczać, że te bardzo wyjątkowe doświadczenia Stewarda stanowiły istotny czynnik, który wpłynął na kształt jego ujęcia antropologii.

\section{3. Środowisko rodzinne i wychowawcze}

Badając uważnie życiorys Juliana Stewarda, można stwierdzić, że bardzo silny wpływ na jego poglądy miała sytuacja rodzinna. Już w dzieciństwie zauważa się u niego głęboką niechęć do religii i polityki oraz miłość do środowiska naturalnego, co znacząco wpłynęło na kształt jego późniejszych koncepcji naukowych. Obecność lub absencja tych elementów w jego myśli antropologicznej nie jest przypadkowa.

Źódła niechęci wobec wszystkiego, co łączy się z religią, można tłumaczyć przekonaniami religijnymi jego matki, gorliwej wyznawczyni Kościoła scjentologicznego. Prawdopodobnie właśnie jej wiara i chorobliwe wręcz przywiązanie do kontrowersyjnego nauczania scjentologów były główną przyczyną rozpadu małżeństwa Stewardów oraz tego, że Julian przez całe swe życie żywił głęboką awersję do wszystkiego, co lączyło się z religią. Utożsamiał ją bowiem z dogmatyzmem i irracjonalnością. Uprawiając naukę, Julian Steward zawsze przeciwstawiał religię i naukę, twierdząc, że „wewnętrzny porządek moralny wszechświata jest filozoficzną fikcją".

Jego ożywione zainteresowanie przyrodą należy natomiast jednoznacznie przypisać pozytywnemu wpływowi jego matki. O ile stosunek matki do religii wpłynął bardzo negatywnie na relację jej syna do wiary, o tyle jej upodobanie do wycieczek krajoznawczych i ukochanie przyrody „zaraziło" syna trwającym przez całe życie zainteresowaniem środowiskiem naturalnym i zaowocowało miłością do przyrody.

Niewątpliwy wpływ na przyszłe poglądy Juliana Stewarda miały także jego stosunki z ojcem, które układały się źle od momentu, gdy ojciec porzucił rodzinę (Julian był wówczas chłopcem). Przez całe lata ojciec i syn nie kontaktowali się ze sobą. Poza sporadycznymi przypadkami Julian nie otrzymywał od, będącego w dobrej sytuacji finansowej ojca, żadnego wsparcia materialnego. Jego niechęć do ojca wyrażała się w antypatii do wszystkiego, z czym go utożsamiał. Thomas Steward był baptystą i republikaninem, a więc jego syn przez całe swe życie był areligijnym demokratą. Natomiast aktywność ojca na gruncie społeczno-politycznym spowodowała, że Julian skwapliwie unikał jakichkolwiek wypowiedzi na tematy polityczne i angażowania się w kwestie społeczne.

Innymi ważnymi osobami, które wpłynęły na kształtowanie się intelektualnych zainteresowań Stewarda byli: twórca Deep Springs College - Lucien Lucius Nunn oraz tamtejsi wykładowcy, a szczególnie profesorowie Burr i Srager. Ten ostatni nauczył Stewarda krytycyzmu w stosunku do poglądów innych i wy- 
pracował w nim umiejętność tworzenia niezależnych przekonan. ${ }^{11}$ Chociaż po latach Steward wyraźnie odrzucał twierdzenia, że sytuacja rodzinna czy wykładowcy z Berkeley wywarli znaczący wpływ na jego rozwój, to bardzo wyraźnie podkreślał rolę czasu spędzonego w Deep Springs College. W liście do Alexandra Wetmore z roku 1954 stwierdził nawet, że był to "punkt zwrotny jego życia” i że właśnie tam dokonał się najgłębszy wpływ na jego karierę naukową ${ }^{12}$ Znacznie później wyraził się nawet: „Nie mam pojęcia, kim bym był, gdybym nie uczył się w Deep Springs College". 13

\section{4. Środowisko intelektualne}

We wczesnym etapie badań prowadzonych przez Stewarda wyraźnie zauważa się obecność elementów behawioralnych, których pojawienie się można chyba łączyć z przyjaźnią, a później miłością i małżeństwem Stewarda z Dorothy Bird Nyswander - psycholog pracującą w Utah University. Steward szukał „namacalnych" potwierdzeń stawianych przez siebie tez, które - dzięki Nyswander - próbował uzasadniać przy użyciu metody behawioralnej. Dzięki temu kluczowi lepiej można zrozumieć jego niechęć do jakichkolwiek zagadnień z zakresu religii, które nie sposób było badać tą metodą.

Wydaje się, że wbrew opinii Stewarda nie bez znaczenia w jego rozwoju intelektualnym był kontakt z profesorami z Berkeley: Alfredem L. Kroeberem, Robertem H. Lowie i Edwardem W. Giffordem. Szczególnie Kroeberowi Steward zawdzięcza bardzo wiele, zarówno w kwestii swego rozwoju intelektualnego, jak i poparcia na drodze kariery naukowej. Można powiedzieć, że Kroeber roztaczał nad Stewardem rodzaj patronatu, wynikającego z relacji mistrz-uczeń. Chociaż Steward wyraźnie zaprzeczał, jakoby myśl jego mistrza wpłynęła na ekologię kulturową, to jednak dyskusja z Kroeberem na łamach publikacji wyraźnie wskazywała, że Steward, głosząc odmienne poglądy, nieustannie odnosił się do swego mistrza. Wyraźnie widać to w pracach Stewarda na temat wpływu czynników kulturowych i psychologicznych w badaniu kultur obecnych na obszarze Great Basin. Zdaniem Stewarda, bez znajomości ekologii, która wytycza i warunkuje te czynniki, nie da się zrozumieć społeczności zamieszkujących te tereny. Kroeber

11 Profesor Srager uczył Stewarda matematyki oraz przedmiotów ścisłych (science). Wywarł na tyle znaczące wrażenie na młodym Julianie, że 3 marca 1946 roku podczas spotkania z samorządem studentów swojej alma mater Steward tak mówił o czasie spędzonym w Deep Springs College: „Doświadczyłem [tu - RS] intelektualnego przebudzenia, które było spowodowane częściowo systemem nauczania, który preferował indywidualną pracę studenta z wykładowcą, a po części przez dogłębny sceptycyzm jednego $z$ wykładowców". Wydaje się, że Steward słowa te odnosił właśnie do profesora Sragera. Por. V. Kerns, Scenes from the High Desert..., dz. cyt., s. 49-50.

12 Cyt. za V. Kerns, Scenes from the High Desert..., dz. cyt., s. 6.

13 Por. Tamże, s. 50. 
natomiast stał na stanowisku, że złożoność czynników środowiska i kultury uniemożliwia wyciągnięcie ogólnych wniosków w tej kwestii. ${ }^{14}$ Wydaje się, że Stewardowi bardzo zależało, żeby wykazać odmienność swoich poglądów względem Kroebera, aby nie dać najmniejszych powodów do przypisywania jego mistrzowi wpływu na kształt zapoczątkowanych przez Stewarda koncepcji.

Antropologia amerykańska w latach 1915-1935 była pod mocnym wpływem F. Boasa i jego uczniów, ${ }^{15}$ którzy promowali historyczne podejście w badaniu kultury. Srodowisko to reagowało bardzo zdecydowanie przeciw wszelkim ujęciom ewolucjonistycznym. Przewaga historycyzmu w amerykańskiej antropologii utrzymała się praktycznie do końca II wojny światowej. Boas i zwolennicy historycyzmu odrzucali podstawowe założenie ewolucjonistów, że podobieństwa kulturowe są wynikiem tych samych przyczyn, ponieważ ludzki umysł reaguje w podobny sposób, gdy jest konfrontowany przez podobne warunki środowiska naturalnego. Julian Steward, tworząc ekologię kulturową, znalazł się w samym środku tej dyskusji. Można chyba uznać, że jego koncepcja stanowiła swoistą odpowiedź na stanowisko Franza Boasa i jego uczniów, którzy byli przekonani, iż kultura jest autonomicznym systemem, który może być całkowicie zrozumiały w kontekście kulturowo-historycznym a wpływy środowiska naturalnego nie są potrzebne dla jej zrozumienia. Steward w odpowiedzi na te poglądy tym bardziej podkreślał rolę środowiska i wszystkiego, co się z nim łączy. ${ }^{16}$

Julian Steward już u początków swej pracy naukowej zerwał z obowiązującym wówczas trendem deterministycznym i posybilistycznym, podkreślając znaczenie metody porównawczej dla badania przyczynowych związków między strukturą społeczną i sposobami zdobywania środków do życia. Jego ujęcie można określić jako funkcjonalistyczne, choć różniące się od funkcjonalizmu brytyjskiego, ze względu na fakt, iż Steward ograniczał rolę instytucji w zachowywaniu równowagi strukturalnej do danego tylko systemu. ${ }^{17}$

14 Dyskusja między Stewardem i Kroeberem odbyła się w ramach wzajemnych publikacji. Steward, który wiele zawdzięczał Kroemerowi, nie odnosił się do niego wprost, choć zorientowani w temacie antropolodzy dostrzegali napięcia na linii Steward - Kroeber. Chodziło tu konkretnie o publikację Stewarda Basin-Plateau Aboriginal Socio-Political Groups (BAE Bulletin No. 120, s. 1-346) oraz pracę Kroebera Cultural and Natural Areas of Native North America (University of California Press 1939). W drugim rozdziale Theory of Culture Change Steward odpowiedział na zarzuty Kroemera, twierdząc, że jego podejście różni się od „relatywistycznych koncepcji historii kulturowej”. Wskazał, że ekologia kulturowa zwraca uwagę na lokalne środowisko jako „ponadkulturowy czynnik, który może wyjaśnić konkretne cechy kulturowe”. Por. V. Kerns, Scenes from the High Desert..., dz. cyt., s. 255-258.

15 Wśród najważniejszych propagatorów koncepcji historycznej byli, m.in.: A. Kroeber, R. Lowie, E. Sapir, P. Radin, R. Benedict, A. Goldenweiser i wielu innych.

16 L. E. Sponsel, Cultural Ecology and Environmental Education, [w:] Journal of Environmental Educations, Vol. 19, 1987, s. 33.

17 Por. E. Moran, Human Adaptability. An Introduction to Ecological Anthropology, Westview Press 2000, s. 47-48. 
W okresie długotrwałego poszukiwania pracy w roku 1934 Steward wyznaczył sobie „długoterminowy plan” badań antropologicznych przy użyciu metody ekologii kulturowej. Stwierdził wówczas, ze inspiracją do ekologicznego ujęcia antropologii było przypadkowe spotkanie podczas górskiej wędrówki pewnego botanika zainteresowanego ekologią roślin. ${ }^{18}$ Zawsze podkreślał jednak, że dochodzenie do ekologii kulturowej zawdzięcza tylko sobie. Określił to nawet jako „bardzo samotną drogę”, która doprowadziła go do wypracowania takiego właśnie ujęcia badań antropologicznych. Wielokrotnie odżegnywał się też od jakichkolwiek wpływów innych uczonych na kształt swojej koncepcji. Szczególnie odcinał się od wpływu ze strony swego kolegi Williama D. Stronga, który interesował się ekologią zwierząt i, prowadząc prace terenowe na społecznościach potomków grup łowiecko-zbierackich, dzielił się ze Stewardem swymi opiniami i wynikami badań. ${ }^{19}$

Współpraca Stronga i Stewarda początkowo układała się dobrze, ponieważ prowadzone przez nich badania wzajemnie się uzupełniały: Steward koncentrował się na aspekcie etnologicznym, podczas gdy Strong - archeologicznym. W końcu lat trzydziestych Steward uważnie śledził badania Stronga na temat patrylinearnych grup i sporo mu w tym temacie zawdzięcza. Ich przyjacielskie relacje i koneksje Stronga przyczyniły się do przyjęcia przez Stewarda posady w Columba University. Niestety, był to jednak okres, w którym dawni koledzy poróżnili się. ${ }^{20}$ Wydaje się jednak, że wbrew temu, co twierdził Steward, luźne i liczne rozmowy ze Strongiem na temat ekologii zwierząt, łowiectwa i innych zagadnień, były prawdopodobnym źródłem inspiracji Stewarda w sprawie ekologii kulturowej. Podobnie jak przelotne spotkanie $\mathrm{z}$ anonimowym botanikiem, które wytyczyło kierunek zainteresowań Stewarda na całe jego dalsze życie. ${ }^{21}$

Mówiąc o kształcie ekologii kulturowej i inspiracjach Stewarda w tym względzie, nie sposób nie wspomnieć brytyjskiego geografa C. D. Forde, którego książka Habitat, economy and society (1934) prezentująca badania na temat ekonomii

18 Por. V. Kerns, Scenes from the High Desert..., dz. cyt., s. 153.

19 Jest to wyraźnie widoczne w korespondencji, którą Steward prowadzil pod koniec swojego życia. Szczególnie w liście do Tax’a z 11 lutego 1966, Harrisa z 8 marca 1969, Spetha z 8 sierpnia 1970 i do Murphy'ego z 4 lipca 1971 r. Por. V. Kerns, Scenes from the High Desert..., dz. cyt., przypis numer 49 , s. 376.

20 Momentem krytycznym ich przyjaźni stało się pewne spotkanie, podczas którego Strong przedstawił Stewarda, jako swoją „prawą rękę”, traktując go nazbyt paternalistycznie. Steward nie był w stanie zaakceptować takiej sytuacji. Żona Stewarda w wywiadzie dla V. Kerns potwierdzila, że od tego momentu relacje jej męża i Stronga znacznie się ochłodziły i sytuacja ta była jedną z głównych przyczyn przeniesienia się Stewarda do University of Illinois w Urbana. Por. V. KERNs, Scenes from the High Desert, dz. cyt., przypis numer 30, s. 370.

21 Por. Tamże, s. 276, 154. 
społeczności pierwotnych musiała być Stewardowi znana. ${ }^{22}$ Wydaje się też, że na koncepcje Stewarda przynajmniej pośrednio wpłynęły prace C. O. Sauera, w których Autor bardzo wyraźnie podkreślał rolę środowiska naturalnego. ${ }^{23}$

Są uczeni, którzy twierdzą, że to nie Steward jest twórcą ekologii kulturowej. Uważają bowiem, że Thomas Robert Malthus w książce pt. An Essay on the Principle of Population (1914) pierwszy przedstawił podstawowe idee tej koncepcji. Wydaje się być niemoźliwe, by Steward nie znał publikacji Malthusa. ${ }^{24}$ Można by więc $w$ tym kontekście uważać Stewarda raczej za propagatora niż twórcę tej koncepcji. Steward w swych pracach terenowych wśród Szoszonów jedynie rozwinął koncepcję ekologii kulturowej, dokumentując stosunki społeczno-ekonomiczne indiańskich społeczności a później wypracował teoretyczne podstawy tej koncepcji. ${ }^{25}$

Bezspornym przejawem wpływu debaty naukowej na kształt ekologii kulturowej, jest fakt, iż Julian Steward na początku lat siedemdziesiątych postanowił znacząco przebudować swoją koncepcję i mocno przeredagować Theory of Culture Change. Zmiany w koncepcji ekologii kulturowej byly na tyle istotne, że można nawet mówić o klasycznej i post-klasycznej wersji ekologii kulturowej Stewarda. W pierwszym wydaniu tej książki (1955) istotną rolę w ekologii kulturowej odgrywało jądro kulturowe (cultural core), które w publikacji artykułu Stewarda $\mathrm{z}$ roku 1968 zostało niemal zupełnie pominięte a koncepcja gruntownie zmieniona.

O atmosferze obrony swoich poglądów i dostosowywania pod wpływem narastającej krytyki niech świadczy treść listu Stewarda do Damas’a z 27 stycznia 1970 roku, w którym Steward stwierdził: „Nigdy nie miałem intencji, by wyjaśnienia ekologiczne lub jakiekolwiek całkowite korelacje pomiędzy kulturą a środowiskiem byłyby wyjaśnieniami niezachwianymi” i dalej „Raczej jawiły się one jako empirycznie testowana hipoteza będąca jednak przydatna w tłumaczeniu wyraźnie widocznych przyczyn zmian kulturowych". ${ }^{26}$

Niestety, śmierć przerwała pracę Stewarda nad przeformułowaniem ekologii kulturowej. Jego żona Jane C. Steward próbowała nawet dokończyć dość zaawansowaną pracę męża. Julian Steward, pracując nad zmianami, przyjął jednak metodę przepracowywania konkretnych zagadnień obecnych w książce a nie poprawiania poszczególnych jej rozdziałów. Świadczy to, na ile poważnych zmian

\footnotetext{
22 Por. K. W. Butzer, Cultural ecology, [w:] G. L. Gaile (red.), C. J. Willmott (red.), Geography in America at the Dawn of the 21st Century, Oxford University Press 2004, s. 197.

23 Tamże

24 Por. L. E. SPONSEL, Cultural Ecology and Environmental Education, [w:] Journal of Environmental Educations, Vol. 19, 1987, s. 33.

25 Tamże.

${ }^{26}$ Cyt. za V. Kerns, Scenes from the High Desert..., dz. cyt., s. 302.
} 
chciał dokonać. Niestety, taka metodologia pracy Autora uniemożliwiła proste naniesienie poprawek $w$ dawnej strukturze książki, która z konieczności musiała się znacząco zmienić i chociaż Jane Steward była przez lata sekretarką męża, nie była w stanie dokończyć rozpoczętej pracy. Udało się jej jedynie dokończyć ostatnią książkę Stewarda - biografię Kroebera. ${ }^{27}$

Umiejscawiając ekologię kulturową w ramach antropologii, zwykle łączy się ją z ewolucjonizmem kulturowym i jest ku temu wiele powodów. Wydaje się, że nie jest to jednak bezwzględnie konieczne. Można sobie bowiem wyobrazić podejście antropologiczne uwzględniające aspekt ekologiczny, które nie jest ewolucjonistyczne i nie stosuje ewolucjonistycznych narzędzi badawczych. ${ }^{28}$ Można jednak wyobrazić sobie także sytuację odwrotną, są uczeni określani mianem ewolucjonistów kulturowych, którzy nie stosują podejścia ekologicznego. Koncepcja ekologii kulturowej Juliana Stewarda ma jednak wyraźny charakter ewolucjonistyczny, a element ekologiczny ma w niej istotne znaczenie. Jest to wynik doglębnej refleksji Stewarda i odpowiedzi na odmienne koncepcje Boasa, Kroebera i innych czołowych antropologów amerykańskich tamtego czasu.

\section{Podsumowanie}

W myśl koncepcji Stewarda o wpływie środowiska na kształtowanie kultury, można stwierdzić, że wpływ środowiska naturalnego i społecznego, rodzinno-wychowawczego oraz intelektualnego na Stewarda był na tyle istotny, że nie sposób zgodzić się ze Stewardem, iż ekologia kulturowa jest jego samodzielną i niezależną koncepcją. Wskazuje na to szereg elementów, które wpłynęły na powstanie i kształt antropologii Stewarda. Z jednej strony były to jego osobiste doświadczenia życiowe, które umoźliwiły mu wyjątkowe i oryginalne wskazanie sposobu, w jaki środowisko naturalne rzutuje na kształt kultury danej społeczności ludzkiej. Z drugiej zaś strony były to idee zaszczepione mu przez jego rodziców, wykładowców, przyjaciół i innych uczonych, którzy przez dyskusję i krytykę ujęcia Stewarda wpłynęli na kształt jego koncepcji. Dyskusja z historycyzmem Francisa Boasa i przyjęcie ewolucyjnej ścieżki rozwoju kultury również zaważyły na ostatecznej formie jego ujęcia antropologii.

Wbrew zapewnieniom Juliana Stewarda o całkowicie samodzielnym tworzeniu tej teorii, jej korzeni można doszukać się w dużo wcześniejszych pracach niektórych uczonych, szczególnie w pracach T. Malthusa, C. D. Forde’a i C. O.

27 Por. V. Kerns, Scenes from the High Desert..., dz. cyt., s. 311; J. H. Steward, Alfred Kroeber, New York-London: Columbia University Press 1973.

28 David Kaplan i Robert Manners uważają, że wiele prac takich antropologów, jak F. Barth, M. Gluckman, E. Colson i C. Geertz mogą być określone jako ekologiczne, ale nie ewolucjonistyczne. Por. D. Kaplan, R. A. Manners, Culture Theory, Englewood Cliffs: Prentice Hall Inc. 1972, s. 75 . 
Sauer'a. Wpływ ten jest na tyle zauważalny, że niektórzy znawcy zagadnienia nawet odrzucają stanowisko, iż to Julian Steward jest twórcą ekologii kulturowej.

Podsumowując biografię Stewarda, Virginia Kerns wymienia całe grono ludzi, którzy mieli wpływ na jego rozwój naukowy i powstanie koncepcji ekologii kulturowej. Wśród nich na czoło wysuwają się takie postacie, jak jego rodzice Grace i Thomas Steward, obie żony: Dorothy Nyswander i Jane Cannon, założyciel Deep Springs College - Lucien Nunn i profesorowie tej uczelni Srager i Burr, jego koledzy Duncan Strong, Ralph Beals oraz wykładowcy i mentorzy: Alfred Kroeber, Robert Lowie, Edward Gifford a także przyjaciele Carl Sauer i Oskar Schmieder. Wydaje się, że pomimo zastrzeżeń samego Stewarda, bez obecności tych osób w jego życiu ekologia kulturowa by nie powstała i nie miałaby kształtu, jaki nadał jej Julian Steward. ${ }^{29}$

Zebrane materiały wskazują też, że krytyka koncepcji Stewarda spowodowała na tyle istotne jej modyfikacje, że można nawet mówić o dwóch odmiennych stadiach ekologii kulturowej. Nieustanna dyskusja środowiska naukowego była na tyle znacząca, że Steward postanowił dokonać dogłębnej rewizji swojej koncepcji. Niestety, śmierć przerwała jego pracę. Kontynuatorzy Stewarda, którzy wykorzystując tę metodę do prowadzenia współczesnych badań terenowych, wskazują jednak, ze pomimo krytyki i licznych zarzutów zasadnicze intuicje Stewarda były właściwe. Sam fakt, że do dziśs ukazują się publikacje utrzymane w duchu ekologii kulturowej, najlepiej świadczy o tym, że koncepcja Stewarda jest wciąż atrakcyjną metodą w zrozumieniu zmian zachodzących w ludzkich społecznościach.

\title{
Sources of Julian Haynes Steward's Anthropology
}

\begin{abstract}
Julian H. Steward claims that he is the only author of anthropological approach called cultural ecology and no one affected him in the process of working out the concept. However, this essay shows that there are three main sources which influenced Steward: social and natural environment, family and educational background, and intellectual community. All of these sources affected him on different levels but without their influence Steward would not create such an original concept of anthropological approach. This essay points out the importance of Steward's hard work on a farm during his study in Deep Springs College and the significance of natural environment of California. It emphasizes the role of Steward's parents, his college educators and professors in Berkeley,
\end{abstract}

29 Por. V. Kenns, Scenes from the High Desert..., dz. cyt., s. 326. 
as well as his personal experience during the Great Depression. Finally, this article describes the influence of intellectual community on Steward, especially by F. Boas, A. Kroeber and publications of T. R. Malthus, C. D. Forde, C. O. Sauer and many others.

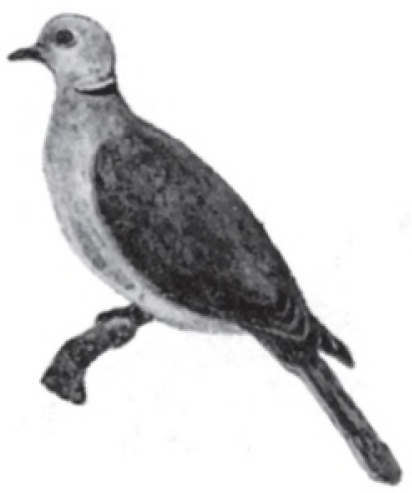

\section{Sierpówka}

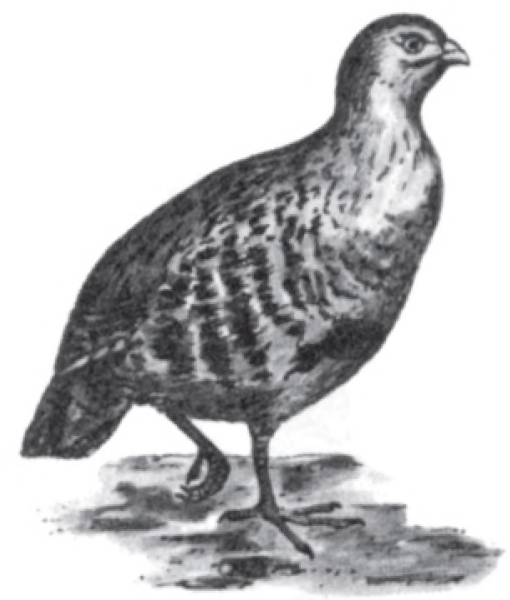

Kuropatwa 